Social Enterprise Journal Vol. 7 No. 1, 2011 pp. 69-85

Emerald Group Publishing Limited 1750-8614 DOI 10.1108/17508611111130167

\title{
Social enterprise in South Korea: history and diversity ${ }^{1}$
}

\author{
Eric Bidet \\ Faculty of Law, Management and Economics, Le Mans University, Le Mans, France, and \\ Hyung-Sik Eum \\ Centre for Social Economy, University of Liege, Liege, Belgium
}

\begin{abstract}
Purpose - This paper aims to deal with the history and main features of social enterprises in South Korea, where a specific legal framework was enacted in 2006.

Design/methodology/approach - The analysis emphasises an economic sociological approach mixing economic considerations, political features and social aspects. The mobilised information comes from previous works realised by the authors on that topic as well as from updated statistics and data about policies, laws and regulations.

Findings - The study underlines that the emergence of social enterprises in South Korea was rooted in civil society and citizens' movements before it became a priority on the government's agenda. The result is the co-existence of several forms of social enterprise with distinctive features: social enterprises certified by the official label, on the one hand, and de facto social enterprises, defined as such because of their practices, goals and values, on the other hand. Such a situation generates a growing tension between the priorities and values emphasised by the political sphere and by the civil society.

Research limitations/implications - Social enterprise is an emerging field of interest and a recent phenomenon, constantly in progress; consequently, systematic data on the field are still lacking, and researchers do not have enough hindsight to learn definitive lessons and draw broad conclusions of statistical significance.

Originality/value - The paper sheds light on a phenomenon that is multi-dimensional and is rapidly evolving. It provides a better comprehension of South Korean political choices and socio-economic changes and can help to anticipate future evolutions and to shape related policies to deal with work integration and the promotion of welfare-mix in the field of social services provision. It also brings information and learning for cross-country comparative studies. Keywords South Korea, Society, Non-profit organizations, Social enterprise, Social services Paper type Research paper
\end{abstract}

\section{Introduction}

As stressed by Defourny and Nyssens (2010), the social enterprise concept has emerged at a very similar moment in Europe, at the initiative of the EMES European Research Network[1] and in the USA, in relation with active lobbying by American business schools, especially the Harvard Business School, which launched the Social Enterprise Initiative in 1993[2]. In both contexts, this concept was an attempt to formalise and provide a common framework for a set of experiences that had emerged a few decades before, in the 1970s for the earliest.

Following the Italian policy of the early 1990s and picking up elements of the early works by the EMES Network, several European countries introduced new legal frameworks, considered as relevant to deal with the two main issues they were facing: a permanency of mass unemployment, affecting a growing part of their population, and a rising demand for social

\footnotetext{
1 The authors would like to thank Jacques Defourny and Sophie Adam for their helpful remarks as well as Helen Robinson for her editorial work.
} 
services, in relation with structural trends that generated a concern for care for the elderly, childcare, environmental issues, citizen's participation and local development.

Since the mid-2000s, several Asian countries, faced with very similar socio-economic challenges, with growing difficulties on the labour market, and with one of the world's most rapidly ageing population, have been showing a strong interest in the European and American experiences of social enterprise. In South Korea, the term social enterprise itself began to be used around 2002, but the emergence of such initiatives and a form of governmental intervention in the field had already appeared at the beginning of the 1990s.

Due to a large part to the active efforts of civil society actors, in 1999 the Korean government implemented the National Basic Livelihood System (NBLS). Under this system, people under a certain level of resources and meeting a series of conditions are eligible to receive public aid in order to reach this level of resources (precisions on this scheme are given in part three hereafter). Those, among eligible persons, who are able to work, must engage in a work integration programme in order to get the full support. This first step was followed in 2006 by the enactment of the Social Enterprise Promotion Act, which contributed to the broad recognition of the concept of social enterprise by the public and the organisations themselves.

In order to understand the history and diversity of social enterprises in South Korea, this paper proposes to start, in part one, with a description of the particular situation of the South Korean labour market, with a view to explaining the rise of the concern for work integration in the country. Then it presents, in part two, other factors that directly contributed to the recent development of social enterprise, including the enactment of the Social Enterprise Promotion Act in 2006. It finally describes, in part three, the different forms of social enterprise existing in South Korea, with a concern not to limit the analysis to certified social enterprises, labelled by the related law.

\section{The labour market: recent evolutions and main features}

Compared to other OECD countries, the Korean labour market presents a general situation that many other developed countries, especially the European ones, could envy: the unemployment rate has for long been kept steady under 5 per cent, and more often even under 4 per cent - with the exception of the two years that followed the late 1990s' economic crisis (1998 and 1999), when it reached, respectively, 6.8 and 6.3 per cent. As for the Korean education system, as stressed by the OECD PISA surveys and by most economic works following the endogenous growth theory, it is considered as one of the best performing in the world, with only 3 per cent of a generation not completing high-school (the lowest rate in the world) - thus providing a human capital that constitutes a major and stable resource for the national economy.

After the two difficult years of 1998 and 1999, the South Korean economy quickly recovered, and the situation of the labour market rapidly improved until 2002. Then, as shown in Table I, the general situation on the labour market deteriorated for three years (2002-2005) before improving again, with a decrease of the unemployment rate (which started flirting with the 3 per cent level), and a decrease in the number of unemployed persons. However, South Korea could not avoid being hit by the economic crisis, whose effects began to be felt in 2009 , with a 15.5 per cent increase in the number of unemployed persons in one year and a ratio employment/overall population coming back to the 2000 level. More recent data show that 1,169,000 people were unemployed in February 2010, which represents a 244,000 persons or a 26.4 per cent increase year-on-year. The unemployment rate is now close to the 5 per cent level. However, despite this recent worsening, South Korea still has the second lowest unemployment rate - after Norway - among OECD countries. 


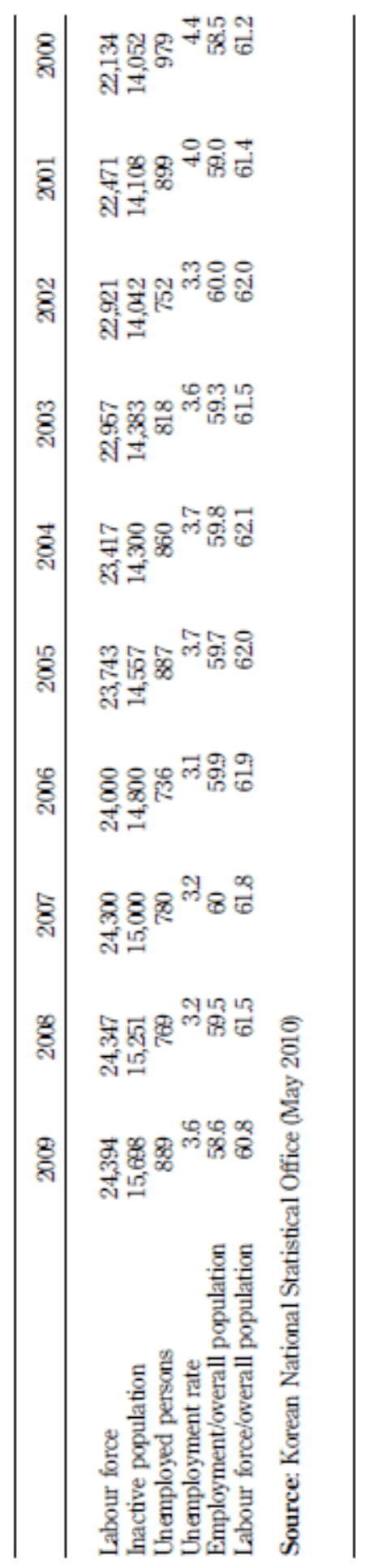

Table I. Basic population and labour market data (in thousands) 


\section{a. The poor average quality of jobs}

This look at the last ten years indicates that the South Korean labour market has relatively good records in terms of quantity of jobs. But the picture is different when considering the quality of these jobs, as can be illustrated through two indicators: the proportion of non-salaried jobs and that of non-regular jobs in the total number of jobs. Indeed, these two types of jobs are usually lower paid, non-secured and less "generous" in terms of social benefits and social protection than regular jobs. As shown in Table II, the Korean labour market is characterised by a high rate of non-salaried jobs. Two sub-categories can be distinguished among workers with non-salaried jobs (referred to as "unpaid workers" in the terminology used by the Korean administration): self-employed workers and unpaid family workers (persons working in their family business without being paid a formal wage). Those non-salaried workers account for some 30 per cent of the total employment in South Korea. By comparison, the average proportion of non-salaried workers within the EU-15 is twice lower (16 per cent) and ranges in most countries between 7 per cent (Luxembourg) and 17 per cent (Spain), with the exceptions of Italy and Portugal (27 per cent) and Greece (40 per cent). The high proportion of non-salaried workers in South Korea is partly due to the managing practices of many Korean companies, which make workers retire at a relatively young age - between 50 and 55 for most of them. When they leave, these workers receive a lump-sum, which they often use to launch a business, as they usually cannot find a decent salaried job because of their age. As a consequence, the proportion of self-employed in the over-50 age group is close to 60 per cent (whereas it is below 30 per cent for those under the age of 50).

South Korea also has a very high proportion of non-regular salaried jobs (temporary employees and daily workers in Table II) compared to other developed countries. Official statistics reveal that daily workers (i.e. those whose contract has a duration below one month) and temporary workers (i.e. those whose contract has a duration below one year) represent together more than 45 per cent of all salaried workers and some 30 per cent of all workers; by comparison, in a country like the USA, where the labour market is considered as very flexible, daily and temporary workers represent 24 per cent of all workers. This characteristic of the South Korean labour market, combined with the high proportion of non-salaried workers mentioned above, makes South Korea the country with the lowest proportion of regular salaried workers - a rate that can be considered as an indicator of the average quality of jobs - among OECD countries. The poor quality of non-regular salaried jobs is clearly evidenced by the difference in remuneration between non-regular salaried jobs and regular jobs: the OECD (2005) estimated that South Korean non-regular workers were paid some 25 per cent less than South Korean regular workers. According to more recent data published by the Korean Ministry of Labour on its website in May 2010, the difference is even much higher: temporary and daily workers have a real wage accounting for less than 30 per cent of the real wage of regular workers $(817,000$ won vs $2,819,000$ won per month on average in the last quarter of 2009).

A tripartite agreement between employers, trade unions and the government, signed in 1998, allowed massive layoffs; many "secure" jobs were then replaced by daily and temporary jobs. The share of regular workers, which, in 1997, accounted for 54 per cent of salaried workers and 


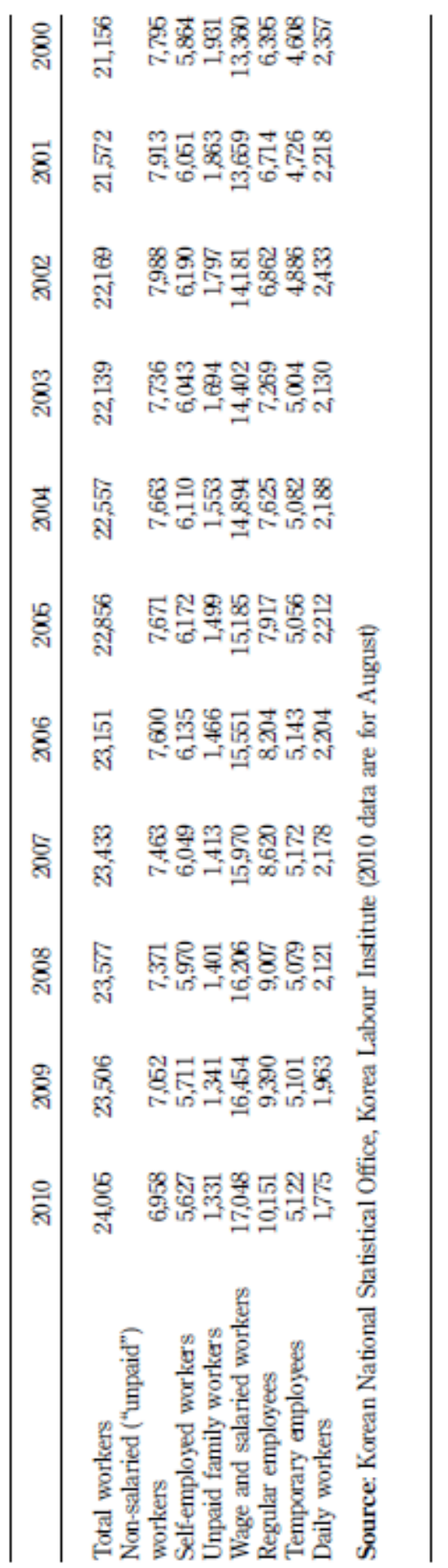

Table II. Status of workers (in thousands) 
34 per cent of total workers, had decreased to 50 per cent of salaried workers and 30 per cent of total workers by 2002. This "substitution" phenomenon explains for a large part the fast decrease of unemployment after the late 1990s crisis (from more than 7 per cent in September 1998, the unemployment rate went down to its pre-crisis level - 2.5 per cent - in 2002): indeed, with its high proportion of non-salaried jobs and its high proportion of non-regular jobs among the salaried jobs, the South Korean labour market as a whole can be considered as a very flexible one, much more flexible than what is said in many economic surveys. More precisely, the South Korean labour market is a dual market: 40 per cent of jobs are secure jobs, on the well-protected primary labour market, while 60 per cent of jobs are unsecure jobs, on the very flexible secondary labour market.

\section{$b$. The risk of social exclusion}

As we have just seen, labour market evolution between 1998 and 2002 showed that when regular jobs disappear, insecure jobs can help curb unemployment. But last years' changes on the labour market have shown that the relation between unemployment and insecure jobs is not a one-way relation: insecure jobs can also easily turn into unemployment. And if social schemes and solidarity processes do not work properly, this unemployment - combined with other handicaps such as social isolation, health problems, psychological disorders, etc. - can easily lead to social exclusion. It can thus be argued that such a labour market structure, with a dominant secondary labour market, presents a high risk of social exclusion, especially if the welfare system does not provide an efficient safety net.

According to Jones (2005), one-third of non-regular workers are not covered by any worksitebased social insurance system. The proportion of uncovered workers is especially high when considering the unemployment insurance scheme. Beside the non-salaried workers, who are by definition not covered, only 65 per cent of the eligible salaried workers and less than 55 per cent of all wage and salary earners are estimated to be actually covered. According to the latest data provided by the South Korean Ministry of Labour, although the number of workers covered by the unemployment insurance scheme has been steadily increasing, from 7,600,000 in 2004 (about 50 per cent of all salaried workers) to 9,800,000 in 2009, the rate of covered workers in the total active population remains below 40 per cent. For the eligible workers, the benefits offered by the scheme are still very limited, both in terms of duration and amounts of money: in 2004 , less than 25 per cent of unemployed persons received unemployment benefits, and the out-of-work benefits (average of net replacement rates over 60 months of unemployment without social assistance) is six times lower in South Korea than it is on average in all OECD countries, and from five to ten times lower than in European countries. That is to say that many South Korean workers still have to rely on the familial solidarity and/or personal savings or face serious financial problems when they become unemployed.

Which categories are the most affected by the precariousness of jobs? Like in other countries, data show a higher proportion of unsecure jobs and unemployment among low-skilled workers and among migrants. But a broader and more complete answer can be found by looking at the gender and age distribution of workers. We have already mentioned that older workers are overrepresented among non-salaried workers, whom we consider as a vulnerable type of workers. Beside the elderly, women are another category facing both a difficult access to the labour market and an extremely difficult access to the primary labour market. 
In its Economic Survey of Korea (2005), the OECD mentions that the participation rate of prime-age women in Korea is one of the lowest in the OECD area. In many developed countries the employment rate of women ranges between 55 and 65 per cent; it is even above 70 per cent in Scandinavian countries. In Korea this rate is only slightly above 50 per cent. However, the deepest difference has to do - even more than with the employment rate itself - with the opportunity for women to have a long-lasting career. Whereas European data, for example, do not show a significant decrease of women's participation rate with age, Korean data show a "break" around the age of 30. Before this age Korean women have almost the same participation rate as Korean men (47.5 vs 46.6 per cent in 2006). But then the difference becomes huge in favour of men: there is almost a 40-point difference in the 30-39 age bracket (93.8 per cent for men vs 56.4 per cent for women), a 30-point difference in the 40-49 age bracket (93.8 vs 65 per cent), and a 20-point difference in the 50-59 age bracket (85.5 vs 65 per cent). Moreover, just like older workers are over-represented in non-salaried jobs, women are over-represented in non-regular jobs: less than 40 per cent of female salaried workers are regular workers.

As we have seen, a significant share of Korean women is not active on the labour market. Those who are receive on average, as a consequence of their overrepresentation in non-regular jobs, lower wages than men (female-to-male earned income is estimated at 40 per cent in the UNDP's Human Development Index for South Korea) and face a higher risk of exclusion from the labour market. Moreover, the welfare system, as already stressed, offers only limited coverage and benefits in case of unemployment. All these factors make the risk of social exclusion higher on the Korean labour market than on other labour markets, with a doubleincome model; indeed, many Korean couples have only one income, and double-income couples cannot rely on a good-level second income or on significant social benefits in case they lose one income.

Thus, behind the general data, the very characteristics of the Korean labour market induce a significant risk of social exclusion for specific categories of persons such as women, older workers, low-skilled workers, migrants, etc. This risk has been neglected by the government as long as the economic situation created the conditions to maintain a high demand on the labour market. With the 1997 crisis, this risk rose significantly and the South Korean government tried to implement various policies dealing with the unemployment and social exclusion of the disadvantaged, and it showed a growing interest for social enterprise as a tool for both work integration and social services provision.

\section{The reorganisation of social services provision and the role of international influences}

Although the problem of the social services provision system appeared on the policy agenda relatively later than the issues more closely related to the labour market, it accelerated the enactment of the Social Enterprise Promotion Act, in 2006, and thus played a prominent role in the recent development and orientation of social enterprises.

Since the country's dramatic industrial development in the 1960s, the Korean society has experienced socio-demographic changes, such as the increase in women's participation in economic activities, ageing population, increase in the number of nuclear families and collapse of traditional local communities and solidarity. Although, as a result of these evolutions, many tasks formerly carried out by housewives within the family had to be organised outside the home, public authorities did not always provide enough means to such an end. In spite of recent efforts 
to catch up, South Korea is still one of the OECD countries with the smallest share of the government budget allocated to social expenditure.

To deal with these issues, the Korean government introduced in 2006 a very ambitious policy, entitled Social Vision 2030. This policy aimed to reinforce the provision of social services by increasing public expenditure, encouraging the formation of a social services market and promoting social enterprises as an important delivery system. More specifically, this policy, based on the idea of connecting the creation of employment with the development of social services provision, gave new opportunities to the non-profits involved in work integration, which suffered brutal competition in conventional markets. In the frame of the policy, several voucher systems were introduced and a new national insurance system for long-term care services, inspired by the German and Japanese experiences, was implemented. In the absence of existing providers for these new services, social enterprises or work project teams preparing social enterprises[3] were encouraged to become providers - or even created with this specific purpose - in the experimental service market resulting from the new policy - a market which conventional enterprises hesitated to enter. Even though the social services sector is not the only one in which social enterprises operate, we can observe that social enterprises in this sector have developed dramatically and remain very dynamic.

One should also emphasise the influence of international policy trends on the shaping of South Korean social policies. Indeed, in a globalised world, more and more policies are shaped under the influence of policies developed in other influential countries and/or recommended by international institutions. Such international trends have a major influence in that they provide a structural framework defining the possible scope of policy choices. A first source of influence at the international level can be found in the OECD; this has especially been true since the country became an OECD member, in 1996. Several reports by OECD experts stressed the need for Korea to develop its social schemes, and especially the pensions and health care systems, including the public ones. There was also a concern, shared by most OECD members, regarding the low cost of labour in South Korea, which was considered as a competitive advantage no longer acceptable from an OECD member. In 1997, after the economic crisis, South Korea took out a loan from the IMF; the policy guideline following this loan restricted the Korean government's choice within the Washington consensus. Under this restricting condition, which constituted a second source of international influence, the Korean government imported the concepts of "workfare" and British New Labour Party's "third way", which both emphasised the responsibilities of beneficiaries of public aid.

The liberal reformist party that governed the country for ten years (1997-2007) promoted a move of social policies towards marginalised and disadvantaged groups and more generally towards social justice. It also supported the idea that civil society could contribute to the shaping of social policies (which had hitherto mainly been decided by elite bureaucrats) and should be consulted on this matter. However, this trend remained actually very constrained by the primacy of the workfare philosophy, which restricted both unconditional social benefits and public expenditure. Scholars like Kwon and Holliday (2007) conclude that "the extensions [of the welfare state] that took place in the late 1990s turn out to have been rather modest". Indeed, rather than significantly reinforcing the public infrastructure of social welfare, the Korean government tried to organise and mobilise civil society actors as part of the solution to social 
problems. In the same vein, in order to persuade the conservatives, the Korean government emphasised the ideology of "workfare" by defining the "conditional beneficiaries" in a very restrictive way and by implementing a Self-Sufficiency Promotion Programme when it installed the NBLS Programme, in 2000[4].

The social enterprise concept itself was also inspired by foreign experiences. Especially, the social movement organisations that initiated the social enterprise phenomenon found their "ideal models" in social enterprises in Europe and in the USA. The South Korean government itself also referred to foreign experiences of social enterprises in its policy discourse. Such references can be found in the policy of promotion of social enterprise, which resemble the policy of the British government, and in the 2006 Act, which, like the Italian social co-operative law of 1991, distinguishes between "social enterprises providing social services" and "work integration social enterprise" (WISE). We can also observe these various sources of references in the ongoing debates about the interpretation of the social enterprise concept among different approaches in civil society and government.

\section{The different forms of social enterprise in South Korea}

The recent evolutions around the social enterprise concept in South Korea have brought about a terminological confusion. When using the term "social enterprise", some people tend to designate only social enterprises certified by the law. Other people use the social enterprise concept to refer to organisations in several institutional categories, identified as social enterprises on the basis of their function and role, and even though these organisations do not always recognise themselves as social enterprises. Others still refer to an ideal and abstract concept, which does not always correspond to any institutional category but tends to encompass all organizations following a social purpose and involving social innovation in a large sense. As this last approach is rather vague, we will consider, in the present article, social enterprise in South Korea according to first two approaches.

\section{a. Certified social enterprises}

The most obvious form of social enterprises, although it is not the "original" one (i.e. the very first form of social enterprise that appeared in the country), is the certified social enterprise according to the Social Enterprise Promotion Act (which, as has already been said, was passed in 2006). Since the Act prohibits other organizations from using the name "social enterprise", the official use of the term refers only to those certified social enterprises. This Act had initially been proposed by a member of the National Assembly from the conservative opposition party, and it was subsequently reformulated by the Ministry of Labour and the ruling Liberal Party in the framework of a job-creation programme in the social services sector. In the Act, a "certified social enterprise" (Injeung sahoejeokkieop) is defined as "an organization which is engaged in business activities, such as producing and selling goods and services, while pursuing a social purpose of enhancing the quality of local residents' life by means of providing social services and creating jobs for the disadvantaged" (article 2). Organisations that want to obtain the certification should have one of the following legal forms: an associative corporation registered under the civil law; a company registered under the Commercial Act; a non-profit private organisation, a consumer co-operative or a welfare corporation registered according to the laws defining those three last forms (article 8). The organisation must submit an application to the Ministry of Labour (article 7). After deliberation of the Social Enterprise Support Committee, 
under the authority of the Ministry of Labour, the organisation is certified or not as a social enterprise (article 4). In order to be certified, organizations should also provide the proof of the relationship between their activities and a social goal (i.e. an activity benefiting disadvantaged persons or an activity related to environmental issues). There are four different types of social enterprise: the "work integration" type (at least 50 per cent of employees must be disadvantaged persons); the "social services provision" type (at least 50 per cent of the recipients must be disadvantaged persons); the "mixed" type (which combines characteristics of the first two types); and the "others" type (which brings together social enterprises that do not fit in either of the three previous categories, such as social enterprises for environmental activity).

By January 2010, 288 social enterprises had been officially certified. In order to better understand the social enterprise landscape in South Korea, we analysed data about 251 social enterprises which had been certified by July 2009: 110 WISEs (43.8 per cent), 71 enterprises of the "mixed" type (29.2 per cent), 37 enterprises of the "others" type (14.7 per cent) and 33 social services provision enterprises (13.1 per cent). The main activities of these social enterprises were social welfare (52 enterprises, 20.7 per cent of the surveyed organisations); environmental activities, including recycling (41 enterprises, 16.3 per cent); and care services (33 enterprises, 13.1 per cent). The other activities listed as main activities included childcare, education, health and culture. When work integration was the main aim, we could find many examples of enterprises active in manufacturing and other productive activities that were not directly related to social services or public interest services.

At the time when these data were collected, 7,228 workers worked in these 251 social enterprises, which means that the average number of paid workers per enterprise was 28.7 . However, it should be noted that this relatively large number of workers is not a distinctive character of Korean social enterprises; indeed, many organizations certified in the first certification processes were large-size social enterprises, but the number of certified small-size social enterprises has recently began to grow (Ministry of Labour and Research Institute of Social Enterprise, 2009).

Certified social enterprises can receive several types of public support. They can apply for the "Social job creation programme"[5], under which they can receive a time-limited subsidy for additional workers, as well as subsidies to support the creation of two to three posts for skilled workers. They can also benefit from subsidies for consulting and for organising "Social enterprise academies", which are supported by the Minister of Labour in every province in order to spread the notion of social enterprise and to teach the skills needed to launch this kind of initiative.

Finally, the Act encourages private companies to support social enterprises in various ways (financial support, purchasing goods and services produced, and so on); it defines the private companies supporting social enterprises as "connected companies". These connected companies are not directly responsible for the employment of workers in social enterprises (Article 15). They can benefit from tax reduction according to the level of support they provide to social enterprises (Article 16). The rationale of the government was of course that social enterprises with connected companies could be more sustainable than others. In 2010, the government furthermore suggested that private companies be more involved in the development of social enterprise and it removed the limit on shares owned by major shareholders in social enterprises (formerly limited to 50 per cent) in order to enhance private companies' involvement in the latter[6]. 


\section{b. Social enterprises related to the NBLS}

The basis of a comprehensive South Korean work integration scheme emerged with the enactment, in 1999, of an extensive general law that reformed the public assistance programmes: the NBLS Act, which became effective in 2000. In their study of the Korean welfare system, Holliday and Kwon (2007) argue that the NBLS has been "the most distinctive change in the entire reform package" that took place recently in South Korea and that it "posed the greatest philosophical challenge" to what they call "the productivist welfare capitalism in Korea". This Act provides for an allowance to be given to any household living under an absolute poverty line, defined according to the family structure: the threshold was set at 1.36 million wons $(1,200$ US\$) in 2010 for a four-person household, i.e. one-third of the average urban income in South Korea (3.9 million wons in 2009)[7].

The NBLS is a package that includes seven monetary and non-monetary types of support, in relation with several fields (health, education, housing, etc.); one of these fields is work integration, and the specific financial support-linked hereto is allocated within the so-called "Self-Sufficiency Promotion Programme". This support was adapted from the pilot project on self-sufficiency promotion launched in 1996, which had itself been modelled on the pioneer experiences which had erupted in civil society. According to the law, a beneficiary of the NBLS, if considered as able to work, must engage in a work integration scheme in order to get the full NBLS allowance; if he/she does not, the work integration part of the allowance included in the NBLS is supposed to be suppressed. If effectively implemented, this condition would deeply reshape the actual organisation of work integration schemes (according to the law, only certain categories of persons, notably heavily handicapped people, are considered as unable to work). However, only a small portion - a little bit more than 10 per cent - of the beneficiaries of the NBLS who are considered as able to work are actually engaged in work integration activities.

Under the NBLS scheme, work integration activities are being carried out both by the public sector and by civil society organisations. Whereas local public authorities take charge of simple and less productive work programmes for rather disadvantaged beneficiaries, the "selfsufficiency enterprises" ( Jahwalgongdongche) and "work project teams preparing selfsufficiency enterprises" ( Jahwalgeunlo eobdan) are currently organised by 242 "local selfsufficiency centres" ( Jiyeok jahwalsenteo, or LSSCs). LSSCs are based on civil society organisations (such as civic movement organisations, social welfare corporations and religious organisations), but the major part of their budget comes from public subsidies under strict conditions - a situation that has raised debates and conflicts about the real autonomy of LSSCs.

One of the main objectives of LSSCs is the creation of "self-sufficiency enterprises" offering sustainable job places to the poor; in order to achieve this objective, LSSCs organise work teams, mainly composed of those among the beneficiaries of the NBLS who are considered as best able to work, to prepare the setting-up of self-sufficiency enterprises. A self-sufficiency enterprise is defined as an enterprise which is economically sustainable and has a kind of collective ownership. Moreover, at least one-third of its workers must be beneficiaries of the NBLS. If these conditions are met, local authorities may recognise such an entity as a "certified selfsufficiency enterprise" and facilitate and support its economic activities. In 2007, 509 selfsufficiency enterprises, employing a total of 3,245 workers, operated in various fields, such as construction, care services, cleaning, recycling, agriculture, manufacturing and so on (Eum, 2008). Self-sufficiency enterprises are considered as the most important outcome of the work 
integration programme in the NBLS scheme; and with a strong support system and a relatively long history, the Self-sufficiency Promotion Programme has clearly been - and still is - a pioneer and a major basis for social enterprise creation in South Korea. As of March 2010, about 20 per cent of certified social enterprises were self-sufficiency enterprises.

\section{c. Other forms of social enterprises}

Besides certified social enterprises and self-sufficiency enterprises, a few other institutional categories of organisations could be considered as social enterprises, according to definitions developed in the worldwide academic communities - even though not all these organisations recognise themselves as social enterprises. In a research study conducted in early 2007, just before the Social Enterprise Promotion Act came into effect, Eum (2008) gathered data on organisations which could be defined as social enterprises on the basis of the approach developed by the EMES European Research Network[8]. In such a perspective, he identified five main institutional categories and he suggested that almost 1,000 organisations could be considered as social enterprises (see Table III).

To these organisations, which are considered as sustainable in the market, one could add the numerous work project teams aiming to prepare sustainable business organisations. Work project teams can be found within different public schemes, such as the Self-Sufficiency Promotion Programme, the Social Jobs Creation Programme and the Jobs Creation for the Aged Programme. According to the Ministry of Labour, these work project teams could be considered as a form of "pre-social enterprises", and they are eligible for some support programmes such as consulting services.

Most organisations listed in Tables III and IV can be considered as WISEs for the disadvantaged. Across most of these categories, from the governmental point of view, the ideal model of social enterprise is a sustainable enterprise, operating in the market and employing a majority - or the largest possible number - of disadvantaged people, with temporary and partial support from public authorities. Beyond differences across target groups, this is indeed the kind of ideal model which prevails today and is associated with the social enterprise concept in South Korea. Although the Social Vision 2030 policy emphasises job creation through the promotion of social enterprise in the social services sector, the main role that public authorities and the general

\begin{tabular}{llcr}
\hline Institutional form & Target group & $\begin{array}{c}\text { Number of } \\
\text { organisations }\end{array}$ & $\begin{array}{c}\text { Number of } \\
\text { participants }\end{array}$ \\
\hline Self-sufficiency enterprises (2007) & $\begin{array}{l}\text { The poor and the } \\
\text { unemployed } \\
\text { who are able to work }\end{array}$ & 509 & \\
Business run in senior clubs (2007) & $\begin{array}{l}\text { The elderly } \\
\text { WISE-like professional rehabilitation }\end{array}$ & 77 & 3,245 \\
workshops (2006) & The handicapped & 202 & 831 \\
Independent workshops (2006) & The handicapped & 128 & 7,206 \\
Standard workshops (2006) & The handicapped & 35 & 4,153 \\
Others (2007) & \multicolumn{1}{c}{-} & 18 & 1,503 \\
Total & & 969 & 420 \\
Source: Eum (2008) & & 17,367 \\
\hline
\end{tabular}

Table III. Social enterprises by institutional forms 


\begin{tabular}{llrr}
\hline Types of work project teams & Target group & $\begin{array}{r}\text { Number } \\
\text { of teams }\end{array}$ & $\begin{array}{r}\text { Number of } \\
\text { participants }\end{array}$ \\
\hline $\begin{array}{l}\text { Market-type self-sufficiency work project } \\
\text { teams (2006) }\end{array}$ & $\begin{array}{l}\text { The poor and the } \\
\text { unemployed who are able to } \\
\text { work }\end{array}$ & 678 & 5,568 \\
$\begin{array}{l}\text { Self-sufficiency work projects teams } \\
\text { funded by non-public resource (2006) }\end{array}$ & $\begin{array}{l}\text { Themployed who are able to } \\
\text { work }\end{array}$ & 224 & 4,794 \\
$\begin{array}{l}\text { Social jobs work project teams (2007) } \\
\begin{array}{l}\text { The unemployed } \\
\text { the elderly (2006) }\end{array}\end{array}$ & The elderly & 376 & 7,546 \\
Total & & 304 & 7,061 \\
Source: Eum (2008) & 1,582 & 24,969 \\
\hline
\end{tabular}

Table IV. Work project teams related to public schemes

public expect social enterprises to play remains concentrated on the employment of disadvantaged people.

Business run in senior clubs. Faced with the rapid ageing of its population, the Korean government launched in 2004 a "Job creation for the elderly" programme. This programme includes different measures, such as the creation of temporary job places, the promotion of volunteering, the provision of information about available job places and the allocation of incentives to enterprises employing the elderly. This programme is carried out by various organisations: local governments, community welfare centres, welfare centres for the elderly, Korean associations of elderly people and senior clubs, which are welfare centres specialised in creating job places for the elderly.

In various programmes run by senior clubs, there are enterprise-like organizations composed of elderly people. Usually, these organisations are founded with the support of senior clubs, such as an amount of capital and temporary job places in the initial stage, but they are mainly run with the income generated by commercial activities. In many cases, the income that the elderly can secure through their participation in such businesses is not sufficient to cover all their living costs; however, the purpose of this programme is not only to provide economic support to the participants, but also to support their social integration through economic activities. In 2007, 77 enterprise-like organisations, employing a total of 831 elderly persons, were run in 40 senior clubs. They mainly worked in artisanal manufacturing, social services and small restaurants.

WISEs for the disabled. Policies for work integration of the disabled[9] have been implemented through various schemes since the 1980s. The organizations participating in three schemes in particular could be considered as social enterprises.

First of all, some "professional rehabilitation workshops" could be regarded as social enterprises. In fact, many of these workshops do not operate as places of employment but as places for social activities and rehabilitation; in these organisations, economic aspects are not generally very significant. However, some sub-types of professional rehabilitation workshops are requested by public authorities to have a more enterprise-like management, and these professional rehabilitation workshops operate like typical work integration social enterprises. According to Eum (2008), there were 202 such WISE-like professional rehabilitation workshops in 2006. Most of them ( 86.2 per cent) were in the manufacturing sector. On average, these professional rehabilitation workshops had 36 workers, among which 30 were persons with disabilities. 
"Independent workshops" constitute a second type of organisations that could be considered as social enterprises. These are organisations where at least 30 per cent of the workers are disabled and more than 50 per cent of the disabled workers have serious handicaps. In 2006, there were 128 such independent workshops, employing more than 4,000 workers, among which two-thirds were disabled workers. Their main field of activity was manufacturing (75.8 per cent), like it was the case for other types of WISEs for the disabled.

Finally, "standard workshops" - which were introduced in 2001 with a view to shaping a model enterprise for the disabled, and involve large public subsidies - constitute the third type of organisations that could be considered as social enterprises. In order for an organisation to be recognised as a standard workshop and receive a public subsidy, more than 30 per cent of all its workers must be disabled workers, and more than 50 per cent of the disabled workers should have serious handicaps. Moreover, after receiving public subsidies, standard workshops must employ a minimum of an additional ten workers with serious handicaps, and they must maintain the employment of all the disabled workers during seven years at least. In 2006, there were 35 standard workshops, mainly working in manufacturing. They employed a total of 1,503 workers, half of them with disabilities.

Beside public subsidies, these three types of WISE for the disabled can benefit from the "Related employment programme". Under this programme, enterprises requested to hire disabled workers[10] may alternatively choose to purchase products from WISEs belonging to one of the three types of organisations described above. It can thus be said that, even though the term "social enterprise" itself was not used to refer to these three categories, South Korean public policies have begun to recognise the concept of WISE. It also seems that the social enterprise concept, after the enactment of the Social Enterprise Promotion Act, has had a significant influence on the modernisation of WISEs for the disabled. It has been reported that 25 professional rehabilitation workshops and eight standard workshops had been certified as social enterprises by the end of 2009 (Ministry of Labour and Research Institute of Social Enterprise, 2009).

\section{Conclusion}

Since the 1997 economic crisis, in relation to both the situation on the labour market and social services provision issues, social enterprise has gradually become a topic of interest in South Korea. This interest seems important enough to say that social enterprise is not merely a fashionable discourse but rather an important response by civil society and public authorities, confronted with structural social changes resulting in new needs. It can also be argued that the concern for work integration emerged in line with specific features of the labour market. The interest for setting up a new social services provision system and the influence of international policy trends have also played a role as structural factors that facilitated the emergence of social enterprises and shaped the dynamics of their development. Among these factors, the specific features of the labour market are particularly important when it comes to explaining why the need for organisations creating new employment opportunities, particularly for the disadvantaged, proved to be crucial in the South Korean context.

The concept of social enterprise first emerged in the country in the early 1990s, in South Korean social movements; it has then been developed in the course of an interaction between these social movements and the government, since the late 1990s, during the economic crisis and the subsequent recovery. In 2006, this interaction led to the enactment of a specific law for 
the promotion of social enterprise, which, in spite of its limitations, can be considered as a form of governmental acknowledgement of this specific type of enterprise. Analysis of the path followed by the social enterprise concept in South Korea shows that this country has built up, in less than 15 years, what took 30 years in some European countries, with the installation of the NBLS in 2000 and the enactment of the Law for the promotion of social enterprise in 2006.

The evolution observed is in line with the traditional top-down culture of South Korea, but also involves common features with most European experiences, based upon a bottom-up movement, often launched by civil society and then acknowledged by the state. From this point of view, we can say that the development of the social enterprise concept in South Korea illustrates an important change in the relations between civil society, the state and the market as well as in their respective roles, as it does at a broader international level. What is more specific to South Korea is the way in which the government appropriated the terminology itself. Today the use of the term "social enterprise" requires a governmental certification and the official website of social enterprise is a governmental one. One can perceive here the long tradition of state monitoring which is the mark of a state control over civil society rather than a state recognition of the latter.

Whereas there has been a consensus on the enactment of this Act in the government and in political circles, it is remarkable that the Act has been met with doubts among actors in the field, because most initiatives have since been organised in a top-down way. Many actors in the field also contested the government's intention to get private companies involved in social enterprise development. However, since it was passed in the National Assembly, the Act has become a strong leverage for the government to shape social enterprise, both in reality and as a concept.

Altogether, the content of the Social Enterprise Promotion Act should be regarded as the result of interactions among various normative interpretations in the field and on the government's political agenda. Backed up by the Act, organisations in various institutional categories have begun to reinterpret themselves in the light of the social enterprise concept. We can foresee that this kind of interactive process between legislation and self-perception of actors will continue and may lead to a larger consensus on the notion of social enterprise.

\section{Notes}

1. Available at: www.emes.net

2. Available at: www.hbs.edu/socialenterprise

3. In the Korean schemes dealing with social enterprises, there are several programmes subsidising intermediary organisations (local self-sufficiency centres, senior clubs and NGOs) in order to organise and support, in a so-called "preparation period" of two to three years, some project teams which are expected to be subsequently transformed into social enterprises.

4. A person who meets the economic conditions to be eligible as a beneficiary but, at the same time, is considered as being able to work receives a full benefit only when participating in activities within the Self-Sufficiency Promotion Programme. More details on this will be provided in the next section of the present article.

5. The "Social job creation programme" is a public scheme providing temporary and mainly occupational jobs to the unemployed in various types of work with a general interest purpose. A part of the Social job creation programme can be used by NGOs aiming to create social enterprises in social and public services and, since 2008, also by certified social enterprises. In 2009 , more than 50 per cent of social enterprises - 133 social enterprises out of $251-$ benefited from this programme. With the "Self-Sufficiency Promotion Programme" presented hereafter, this programme, which began in 2003, has been an important support policy for promoting social enterprises. The programme changed its name to "(Pre-)social enterprise job creation programme" in 2010.

6. See http://news.molab.go.kr (accessed 1 April 2010).

7. By comparison, this ratio is a little bit higher in France, where the absolute poverty threshold is set at 38 per cent of the average income (11,000/30,000 euros annually in 2006). Moreover 
the French minimum income system also includes other social benefits (housing and health), in addition to the allowance itself. It also has to be noted that the data for France is certainly more representative of the whole population; the Korean average urban income is mostly calculated upon the situation of regular workers, who are far from representing the whole population of workers, as we explained in part 1.

8. This means that he considered a broad "galaxy" of social enterprises on the basis of EMES indicators (see Defourny and Nyssens, 2010).

9. The term "disabled" refers here to persons with physical or mental difficulties. To benefit from diverse welfare programmes, the disabled should be officially registered according to the "Disabled Welfare Law". Other types of difficulties, such as social handicap, are not yet officially recognised in South Korea.

10. According to the Disabled Employment Promotion Law, all types of enterprise with more than 50 employees should employ from 2 to 3 per cent of disabled workers in their total workforce.

\section{References}

Defourny, J. and Nyssens, M. (2010), "Conceptions of social enterprise and social entrepreneurship in Europe and the United States: convergences and divergences", Journal of Social Entrepreneurship, Vol. 1 No. 1, pp. 32-53.

Eum, H. (2008), Social Economy and Social Enterprise in South Korea, Working Together Foundation, Seoul (in Korean).

Holliday, I. and Kwon, S. (2007), "The Korean welfare state: a paradox of expansion in an era of globalisation and economic crisis", International Journal of Social Welfare, Vol. 16 No. 16, pp. 242-8.

Jones, R. (2005), "The labour market in Korea: enhancing flexibility and raising participation", OECD Economic Department Working Papers, No. 469, Paris.

Ministry of Labour and Research Institute of Social Enterprise (2009), Social Enterprise Directory, Ministry of Labour and Research Institute of Social Enterprise, Seoul (in Korean).

OECD (2005), Economic Survey of Korea, OECD, Paris, p. 2.

\section{Further reading}

Bidet, E. (2009), "The rise of work integration and social enterprise in South Korea", EMES Conferences Selected Papers Series, ECSP-B08-17, Lie'ge, available at: http://emes.net/fileadmin/emes/PDF_files/Selected_Papers/Serie_1_Theme_4/ECSPB08-17 Bidet .pdf (accessed 30 October 2010).

Borzaga, C. and Defourny, J. (Eds) (2001), The Emergence of Social Enterprise, Routledge, London.

Borzaga, C. and Spear, R. (Eds) (2004), Trends and Challenges for Co-Operatives and Social Enterprises in Developed and Transition Countries, Edizioni31, Trento.

Davister, C., Defourny, J. and Gre'goire, O. (2004), "Work integration social enterprises in the European Union: an overview of existing models", PERSE Transversal Report, EMES Working Paper Series, No. 04/04, Lie`ge, available at: www.emes.net/index.php?id1/43 (accessed 30 October 2010).

Jahwal Jeongbo Center (Self Employment Development Agency - SEDA) (2006), The Current Situation of Self-Help Support Centres Activity, No. 1, Self Employment Development Agency-SEDA, Seoul (in Korean).

Ministry of Health and Social Affairs (2006), Guide for Work Integration in 2006, Ministry of Health and Social Affairs, Seoul (in Korean).

Ministry of Labour website (2010), Statistics, Ministry of Labour, available at: www.molab.go.kr/ (accessed 30 October 2010).

National Statistical Office website (2010), Economic Trend, National Statistical Office, available at: http://kostat.go.kr (accessed 30 October 2010). 
Nyssens, M. (Ed.) (2006), Social Enterprise - At the Crossroads of Market, Public Policies and Civil Society, Routledge, London and New York, NY.

OECD (2000), "Labour market reform and social safety net policies in Korea", OECD Observer, October issue, Paris.

Peck, J. (2001), Workfare States, The Guilford Press, New York, NY.

Presidential Commission for Employment (2006), Employment in Social Services, PresidentialCommission for Employment, Seoul (in Korean).

Social Enterprise website (2010), available at: www.socialenterprise.go.kr/ (accessed 30 October 2010).

Spear, R. and Bidet, E. (2005), "Social enterprise for work integration in 12 European countries: a descriptive analysis", Annals of Public and Cooperative Economics, Vol. 76No 2, pp. 195-231.

UK Department of Trade and Industry (2002), Social Enterprise - A Strategy for Success, DTI, London.

\section{Corresponding author}

Eric Bidet can be contacted at: ericbidet@ hotmail.com 